\title{
Studi pemanfaatan limbah pelepah sawit sebagai bahan baku pulp metode Organosolv disertai hidrotermal pretreatment
}

\author{
Rachmawati Apriani ${ }^{*}$, Ni Njoman Manik Susantini ${ }^{1}$ \\ ${ }^{1}$ Program Studi Teknologi Pengolahan Pulp dan Paper, Fakultas Vokasi, Institut Teknologi dan Sains Bandung \\ ${ }^{1}$ Corresponding author: rachmawatiapriani46@gmail.com
}

\begin{abstract}
Abstrak. Penelitian bertujuan menentukan properties strength dari pulp yang berbahan baku pelepah kelapa sawit di Laboratorium Satuan Operasi Pulp dan Kertas. Pelepah kelapa sawit merupakan limbah organik kategori non-wood dengan kandungan selulosa tinggi. Proses pembuatan pulp didominasi oleh kraft yang tidak ramah lingkungan. Salah satu metode pulping lain adalah proses organosolv dengan menggunakan pelarut organik seperti asam asetat yang menghasilkan yield yang lebih tinggi dan properties mekanis. Pengaruh kondisi operasi seperti suhu, waktu, konsentrasi liquor dan perbandingannya penting terhadap properti pulp. Proses menggunakan asam asetat $10 \%$ dan $15 \%$ serta $\mathrm{NaOH} 15 \%$. Pengaruh perbandingan liquor terhadap solid, penambahan aditif soda, suhu operasi dan konsentrasi komponen liquor diteliti untuk mendapatkan nilai optimal dari proses. Pretreatment hidrotermal dilakukan meningkatkan penetrasi dan difusi zat aktif selama proses pulping. Kertas yang dihasilkan memiliki kekuatan tarik yang baik dengan tingginya konsentrasi asam asetat dimana asam asetat $15 \%$ menghasilkan kekuatan tarik sebesar 0,99 $\mathrm{kN} / \mathrm{m}$ sedangkan $10 \%$ menghasilkan $0,63 \mathrm{kN} / \mathrm{m}$ dibandingkan $\mathrm{NaOH}$ sebesar $15 \%$ kurang baik yaitu $0,385 \mathrm{kN} / \mathrm{m}$, maka adanya penambahan LBKP $20 \%$ dapat meningkatkan tensile dikarenakan kandungan serat dari wood. Semakin tinggi konsentrasi asam asetat maka ketahanan sobek semakin kecil. Maka optimum pada $10 \%$ yaitu $228,49 \mathrm{mN}$. Jika di bandingkan dengan $\mathrm{NaOH} 15 \%$ masih kurang baik yaitu $175,73 \mathrm{mN}$.
\end{abstract}

Keywords: Pelepah Kelapa Sawit, Pulping, Pulping Organosolv, Pretreatment Hidrotermal

\section{Pendahuluan}

Bahan bukan kayu (non-wood) merupakan bahan alternatif dalam produksi cellulose dan turunannya. Jerami, tandan kosong kelapa sawit dan pelepah kelapa sawit merupakan limbah industri yang menjanjikan untuk di olah menjadi bahan yang bernilai lebih tinggi. Indonesia memiliki sekitar 10,5865 juta Ha lahan kelapa sawit tahun 2013 (Badan Pusat statistik, 2015). Setiap tahun, 10,88 ton limbah pelepah sawit dihasilkan setiap hektar setiap tahunnya (Kelly-Yong dkk, 2011). Dengan demikian, pada tahun 2013 Indonesia menghasilkan sekitar 310 ribu ton pelepah kelapa sawit setiap harinya. Limbah ini perlu diolah agar memiliki nilai tambah ekonomis. Secara kimiawi, pelepah kelapa sawit mengandung holocellulose dan $\alpha$-cellulose berturut-turut $(82,2 \%)$ dan $(47,6 \%)$ yang lebih tinggi dibandingkan dengan Trembling aspen $(77,8 \%$ dan $43,6 \%)$. Sedangkan kandungan lignin sebesar 15,2\% lebih rendah dibandingkan dengan Trembling aspen $(18,1 \%)$.

Beberapa proses pulping limbah kelapa sawit yang telah dilakukan yaitu soda-anthraquinone, etanol, ethanolamine, soda, kraft dan kraft-anthraquinone. Kraft pulping adalah proses yang paling banyak digunakan saat ini karena memiliki keunggulan dalam properties strength. Zat aktif yang digunakan dapat didaur ulang dan produk samping organik lain yang diperoleh dapat digunakan sebagai bahan bakar. Akan tetapi, kraft pulping memiliki kelemahan terhadap kecerahan pulp yang dihasilkan sehingga diperlukan bleaching. Beberapa teknik bleaching telah dikembangkan namun teknik yang benar-benar bebas chlor menghasilkan pulp dengan propertis yang kurang baik dan biaya tinggi. Selain itu, adanya komponen sulfur pada white liquor kurang ramah lingkungan. Teknik pulping lain yang sedang dikembangkan untuk 
mengatasi masalah pada kraft pulping adalah menggunakan pelarut organik seperti etanol, metanol, asam asetat atau asam format. Proses ini disebut juga dengan Organosov pulping. Teknik ini memiliki keunggulan biaya investasi rendah, efisiensi pulping yang lebih tinggi, produk samping lebih mudah dipisahkan secara destilasi, lebih mudah dalam penetrasi liquor masuk ke dalam chip dan lebih ramah lingkungan (Garrote, 2003).

Beberapa kendala dalam proses pulping dan pembuatan kertas dari non-wood adalah proses penetrasi liquor dan kandungan logam dalam material. Adanya udara yang terperangkap dalam chip dapat menganggu proses pulping karena menurunkan proses penetrasi liquor sehingga diperlukan perlakuan awal. Salah satu proses perlakuan awal adalah pre-steaming dan hydrothermal treatment. Pada proses pre-steaming, digunakan steam suhu tinggi untuk membantu penetrasi liquor masuk ke dalam chip. Proses hidrotermal, selain membantu proses penetrasi juga dapat menghilangkan zat pengotor namun menyebabkan turunnya yield, autohydrolysis hemiselulosa menjadi monosakarida (xylose, glucose, arabinose) (Caparros dkk, 2008, Ferrer dkk, 2013) dan memecah cellulose yang mengakibatkan turunnya tahanan mekanis. Di sisi lain, kandungan logam pada non-wood lebih bervariasi dibandingkan dengan wood (Pahkala dkk, 1999). Logam ini akan mengganggu proses pulping terutama pada proses bleaching menggunakan $\mathrm{H} 2 \mathrm{O} 2$ atau O3, dan menggelapkan pulp dan kertas yang dihasilkan. Logam ini juga menimbulkan korosi pada pipa. Organosolv pulping pada tandan kosong kelapa sawit menghasilkan kandungan logam yang lebih rendah (Gonzalez dkk, 2008) demikian juga proses hidrotermal dapat menurunkan kandungan Kalium hingga 77\% pada tandan kosong kelapa sawit (Prawisudha dkk, 2014)

Beberapa penelitian mengenai pemanfaatan limbah kelapa sawit telah dilakukan. Wanrosli dkk (2007) meneliti pembuatan pulp dari pelepah kelapa sawit menggunakan proses soda dan sulfite tanpa adanya pretreatment. Hasil menunjukkan pulp dari proses soda memberikan propertis yang baik dalam propertis strength namun lemah pada kecerahan sedangkan pada proses sulfite baik pada kecerahan namun rendah dalam propertis strength. Pada proses pulping menggunakan asam asetat sebagai bahan aktif (Wanrosli dkk, 2011), propertis pulp yang dihasilkan seperti kecerahan, tensile, densitas, bilangan Kappa bergantung kepada kondisi operasi seperti suhu, konsentrasi $\mathrm{HCl}$ dan asam asetat yang digunakan. Nilai optimum pada proses ini pada suhu $140{ }^{\circ} \mathrm{C}$, konsentrasi $\mathrm{HCl}$ dan asam asetat sebesar $0,5 \%$ dan $75 \%$ berturut-turut. Ferrer dkk (2013) meneliti pembuatan pulp dari tandan kosong kelapa sawit dengan metode soda-anthraquinone, etanol, dan ethanolamine yang diawali dengan hidrolisis. Pulp yang dihasilkan memiliki kecerahan yang tinggi namun kurang baik dalam propertis strength dibandingkan pulp tanpa diawali hidrolisis.

Kondisi proses pada pretreatment hidrotermal dan pulping Organosolv seperti suhu, perbandingan solid dan liquid, tekanan, derajat keasaman mempengaruhi propertis pulp yang dihasilkan. Adanya pretreatment dapat meningkatkan derajat penetrasi liquor namun menurunkan derajat polimerisasi sehingga menurunkan kekuatan kertas. Oleh karena itu diperlukan studi untuk menentukan kondisi proses yang optimal pada pembuatan pulp dan pelepah kelapa sawit dengan menggunakan pretreatment hidrotermal dan pulping Organosov. Pada penelitian ini, akan diteliti pengaruh pretreatment hidrotermal dengan variable suhu, perbandingan solid-liquid dan pengaruh pulping dengan variabel perbandingan solid-liquid, jenis liquor, konsentrasi liquor dan adanya aditif terhadap propertis pulp dan kertas yang dihasilkan

\section{Metode}

\subsection{Persiapan bahan}

1. Pelepah kelapa sawit dicacah

2. Hasil potongan kemudian dikeringkan menggunakan sinar matahari dan udara sekitar.

\subsection{Proses hidrotermal}

1. Serbuk pelepah kelapa sawit dengan beberapa macam ukuran dicampur dengan air dengan perbandingan sesuai variabel percobaan di dalam reaktor.

2. Memanaskan reaktor pada suhu, waktu dan tekanan sesuai variabel.

3. Setelah proses hidrolisis, solid dipisahkan dengan disaring.

4. Sebagian dari solid dan liquid hasil proses dianalisa menggunakan HPLC. 


\subsection{Proses pulping}

1. Proses pulping dilakukan pada reaktor yang sama dengan yang digunakan pada proses hidrotermal.

2. Cairan pemasak terdiri dari cairan pemasak dengan pelarut organik dengan konsentrasi sesuai dengan variabel dan cairan pemasak untukproses kraft dengan konsentrasi sesuai dengan variabel.

3. Solid hasil hidrotermal dimasukkan dalam reaktor dan dicampur dengan cairan pemasak (jenis dan perbandingan sesuai dengan variabel).

4. Dilakukan proses pulping dengan kondisi operasi (suhu, tekanan, to time dan lama proses) sesuai dengan variabel.

5. Setelah proses pulping, solid dan liquid dipisah menggunakan penyaring untuk dianalisa.

\subsection{Metode analisis}

Pulp dianalisis

1. Yield untuk mengetahui jumlah pulp yang dihasilkan terhadap bahan baku.

2. Viskositas untuk mengetahui derajat polimerasi. Derajat polimerisasi akan menentukan apakah cellulose terdegradasi atau tidak.

3. Bilangan Kappa untuk mengetahui jumlah lignin yang terurai.

4. Brightness untuk mengetahui derajat kecerahan pulp yang dihasilkan.

5. Tear strength untuk mengetahui kekuatan sobek kertas dari pulp yang dihasilkan.

6. Tensile strength untuk mengetahui kekuatan tarik kertas dari pulp yang dihasilkan. Sebelum analisa tear dan tensile strength, pulp lebih dahulu dibentuk membentuk kertas handsheet.

7. Analisa morfologi serat untuk mengetahui morfologi serat terhadap kekakuan serat.

8. Analisa coarseness serat untuk mengetahui derajat kekasaran serat. Derajat kekasaran serat akan berkaitan dengan tear dan tensile strength.

9. Pengujian kadar selulosa dalam pulp.

10. Pengujian panjang serat. Panjang serat berkaitan dengan tear dan tensile strength.

\section{Hasil dan pembahasan}

Tabel 7. Hubungan waktu terhadap massa total setelah impregnasi

\begin{tabular}{|c|c|c|c|c|c|c|}
\hline No & $\begin{array}{c}\text { Massa } \\
\text { aquadest } \\
\text { (gram) }\end{array}$ & Suhu (T) $\left.\mathbf{(}^{\circ} \mathbf{C}\right)$ & $\begin{array}{c}\text { Waktu (t) } \\
\text { (menit) }\end{array}$ & $\begin{array}{c}\text { Overshoot } \\
\left({ }^{\circ} \mathbf{C}\right)\end{array}$ & $\begin{array}{c}\mathbf{P} \\
\text { (bar) }\end{array}$ & $\begin{array}{c}\text { Massa total setelah } \\
\text { impregnasi (gram) }\end{array}$ \\
\hline 1 & 750 & 150 & 30 & 154 & 6 & 1314 \\
\hline 2 & 1250 & 150 & 0 & 154 & 5,5 & 1315 \\
\hline 3 & 1250 & 150 & 30 & 157 & 6 & 1364 \\
\hline 4 & 1750 & 150 & 30 & 164 & 7 & 1973 \\
\hline 5 & 1750 & 150 & 60 & 164 & 7 & 1974 \\
\hline
\end{tabular}

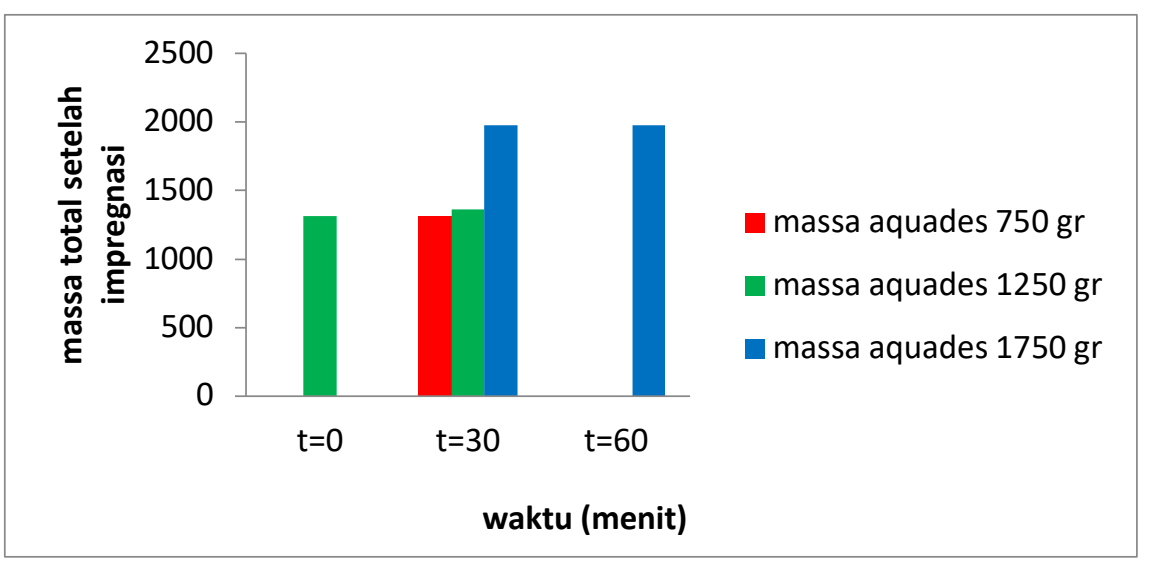

Gambar 10. Hubungan waktu terhadap massa total setelah impregnasi

Semakin lama waktu tunggu maka terjadi kenaikan terhadap massa total setelah impregnasi (Gambar 10). 
Tabel 8. Hubungan Suhu terhadap massa total impregnasi

\begin{tabular}{|c|c|c|c|c|c|c|}
\hline No & $\begin{array}{c}\text { Massa aquades } \\
\text { (gram) }\end{array}$ & $\begin{array}{c}\text { Suhu (T) } \\
\left({ }^{\circ} \mathbf{C}\right)\end{array}$ & $\begin{array}{c}\text { Waktu (t) } \\
\text { (menit) }\end{array}$ & $\begin{array}{c}\text { Overshoot } \\
\left({ }^{\circ} \mathbf{C}\right)\end{array}$ & $\begin{array}{c}\mathbf{P} \\
(\text { bar) }\end{array}$ & $\begin{array}{c}\text { Massa total setelah } \\
\text { impregnasi(gram) }\end{array}$ \\
\hline 1 & 1750 & 125 & 30 & 143 & 4 & 1972 \\
\hline 2 & 1750 & 150 & 30 & 164 & 7 & 1973 \\
\hline 3 & 1750 & 150 & 60 & 164 & 7 & 1974 \\
\hline 4 & 1750 & 175 & 30 & 181 & 11 & 1972 \\
\hline 5 & 1750 & 175 & 60 & 178 & 10 & 1833 \\
\hline
\end{tabular}

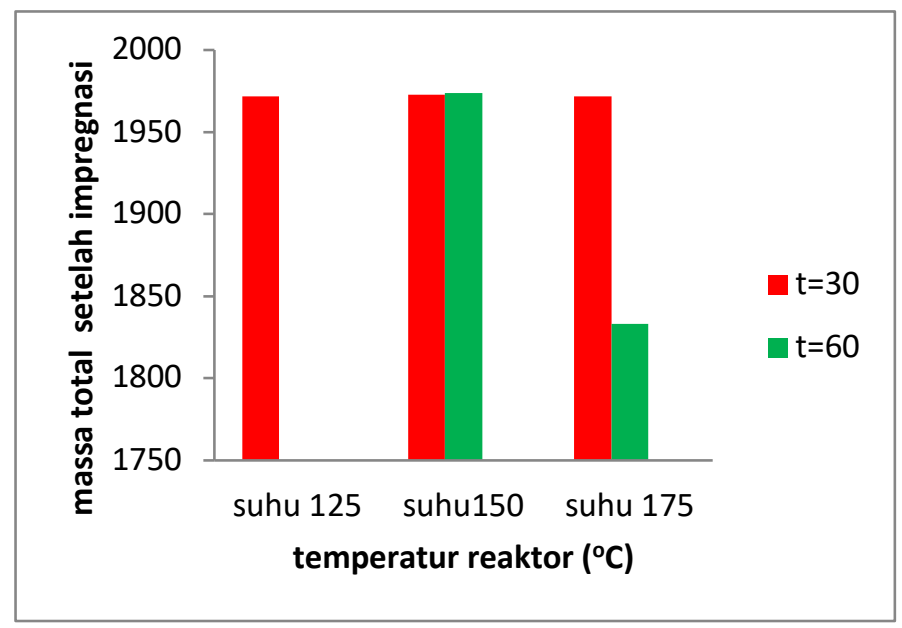

Gambar 11. Hubungan Suhu terhadap massa total impregnasi

Pada waktu tunggu 30 menit, massa total impregnasi cenderung mengalami kenaikan namun tidak siginifikan, dengan semakin naiknya suhu pulping sedangkan pada waktu tunggu 60 menit, massa total impregnasi mengalami penurunan seiring dengan kenaikan suhu pulping. Hal ini menunjukkan bahwa pada waktu tunggu 60 menit terjadi perubahan fase pada liquid akibat kenaikan suhu (Gambar 11).

Tabel 9. Hubungan waktu terhadap volume air setelah impregnasi

\begin{tabular}{|c|c|c|c|c|c|c|}
\hline No & $\begin{array}{c}\text { Massa } \\
\text { aquadest } \\
(\mathbf{g r a m})\end{array}$ & $\begin{array}{c}\text { Suhu (T) } \\
\left({ }^{\circ} \mathbf{C}\right)\end{array}$ & $\begin{array}{c}\text { Waktu (t) } \\
(\mathbf{m e n i t})\end{array}$ & $\begin{array}{c}\text { Overshoot } \\
\left({ }^{\circ} \mathbf{C}\right)\end{array}$ & $\begin{array}{c}\mathbf{P} \\
(\text { bar })\end{array}$ & $\begin{array}{c}\text { Volume air setelah } \\
\text { impregnasi }\end{array}$ \\
\hline 1 & 750 & 150 & 30 & 154 & 6 & 600 \\
\hline 2 & 1250 & 150 & 0 & 154 & 5,5 & 600 \\
\hline 3 & 1250 & 150 & 30 & 157 & 6 & 500 \\
\hline 4 & 1750 & 150 & 30 & 164 & 7 & 1100 \\
\hline 5 & 1750 & 150 & 60 & 164 & 7 & 1140 \\
\hline
\end{tabular}

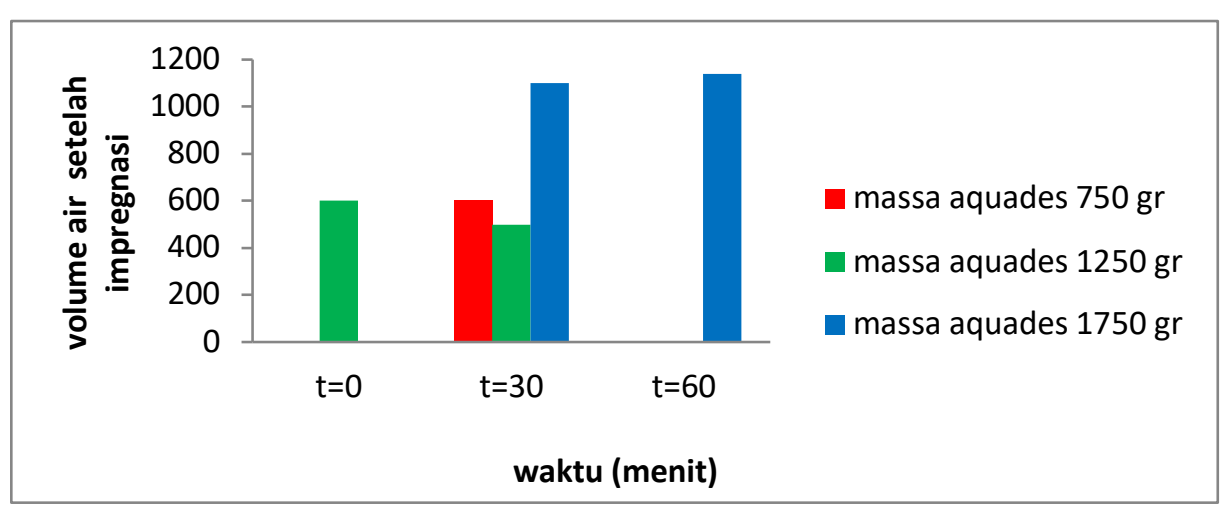

Gambar 12. Hubungan waktu terhadap volume air setelah impregnasi 
Untuk massa aquades 1250 gram, semakin lama waktu tunggu, volume air setelah impregnasi menurun, sedangkan pada massa aquades 1750 gram, semakin lama waktu tunggu, volume air setelah impregnasi semakin meningkat (Gambar 12).

\section{Proses pulping dengan hidrotermal}

\section{Variasi larutan pemasak (asam asetat 15\%)}

Impregnasi : $\mathrm{T}=175^{\circ} \mathrm{C}, \mathrm{t}=60$ menit

Sampel berupa pelepah kelapa sawit sebanyak 802 gram (berat basah setelah proses pretreatment dengan larutan pemasak organosolv yaitu asam asetat sebanyak 19 gram dengan suhu diatur $125^{\circ} \mathrm{C}$ dengan waktu tunggu selama 30 menit.

Aquadest : $1946 \mathrm{gr} / 2000 \mathrm{ml}$

Waktu overshoot : $137^{\circ} \mathrm{C}$

Tabel 10. Proses pulping

\begin{tabular}{|c|c|c|c|}
\hline Waktu & $\mathbf{T}\left({ }^{\circ} \mathbf{C}\right)$ & $\mathbf{P}$ (bar) & Keterangan \\
\hline $15: 59$ & 26 & 1 & Start \\
\hline $16: 09$ & 65 & 1 & \\
\hline $16: 19$ & 118 & 2 & \\
\hline $16: 20$ & 122 & 3 & Holding start \\
\hline $16: 30$ & 133 & 3 & \\
\hline $16: 40$ & 124 & 2 & \\
\hline $16: 50$ & 126 & 3 & Holding stop \\
\hline $17: 22$ & 99 & 1 & Open \\
\hline
\end{tabular}

Setelah proses pulping didapat massa total sampel sebanyak 2075 gram dengan massa air sebanyak 1306 gram, massa padatan $=769$ gram. Lalu dilanjutkan dengan pembuatan handsheet di Laboratorium Pulp dan Kertas ITSB melewati proses beating, penentuan csf 450 dan pembuatan handsheet. Lalu dilanjutkan pengujian sampel di Balai Besar Pulp dan Kertas berupa pengujian tensile strength, tear strength dan brightness. Dilakukan proses bleaching pulp dengan hidrogen peroxide dengan sampel NaoH $15 \%$ ) menjadi TC (total consistency) 0,8\%. Pada sampel terdapat stock yang masih keras sehingga akan sulit untuk dilakukan proses penguraian serat. Konsetrasi larutan pemasak $\mathrm{NaOH}$ divariasikan $10 \%$ dan $15 \%$. Proses pulping dengan menggunakan larutan pemasak berupa $\mathrm{NaOH}$ sebanyak $15 \%$ dari berat kering yang dilakukan di lab pulp dan kertas Institut Teknologi dan Sains Bandung.

Tahapan yang dilakukan pada pembuatan handsheet adalah menentukan moisture (kandungan air) dari sampel yang telah melewati proses impregnasi dan cooking yang bertujuan untuk mengetahui berat kering dari sampel sehingga menjadi acuan untuk menentukan konsentrasi larutan pemasak yang akan digunakan. Setelah proses cooking, sampel melalui proses pengukuran $\mathrm{pH}$ lalu dilanjutkan ke tahapan washing untuk membuat $\mathrm{pH}$ mencapai $\mathrm{pH}$ normal 7 dilanjutkan proses bleaching $\mathrm{H}_{2} \mathrm{O}_{2}$ untuk memutihkan pulp. Setelah bleaching dilakukan proses beating untuk mengurai serat. Sampel pulp dilakukan pengujian bilangan kappa, kadar lignin, kadar selulosa dll di Balai Besar Pulp dan Kertas (BBPK). Consistency dari proses penguraian serat yang digunakan $0,3 \%, 0,67 \%$ dan $0,8 \%$ yang menandakan berapa banyak serat di dalam air. Hal ini akan mempengaruhi hasil akhir dari proses beating (penguraian serat). Seharusnya consistency pada setiap sampel itu sama. Pada pembuatan handsheet pulp dihitung derajat giling (freness) dan 450-500 csf yang bertujuan untuk mengetahui berapa banyak serat yang terfibrilasi (terurai).

Tabel 11. Hasil uji kertas-pelepah sawit dengan larutan pemasak asam asetat

\begin{tabular}{|c|c|c|c|c|}
\hline No & Parameter & Satuan & $\begin{array}{c}\text { Hasil Uji } \\
\text { Asam asetat } \\
\mathbf{1 5 \%}\end{array}$ & \multirow{2}{*}{ Metoda } \\
\hline 1 & $\begin{array}{c}\text { Tensile } \\
\text { strength }\end{array}$ & $\mathrm{kN} / \mathrm{m}$ & 0,99 & $\begin{array}{c}\text { SNI ISO 1924-2- } \\
2010\end{array}$ \\
\hline 2 & $\begin{array}{c}\text { Tearing } \\
\text { strength }\end{array}$ & $\mathrm{mN}$ & 137,30 & SNI 0436:2009 \\
\hline 3 & Brightness & $\%$ & 13,3 & $\begin{array}{c}\text { SNI ISO } \\
2470: 2010\end{array}$ \\
\hline
\end{tabular}

Keterangan : kondisi ruang pengujian : suhu $23 \pm 1^{\circ} \mathrm{C}$; RH $50 \pm 2 \%$ 
Tabel 12. Hasil uji kertas-pelepah sawit dengan larutan pemasak asam asetat dan $\mathrm{NaOH}$

\begin{tabular}{|c|c|c|c|c|c|c|}
\hline \multirow[b]{2}{*}{ No } & \multirow[b]{2}{*}{ Parameter } & \multirow[b]{2}{*}{ Satuan } & \multicolumn{3}{|c|}{ Hasil Uji } & \multirow[b]{2}{*}{ Metoda } \\
\hline & & & $\begin{array}{l}\text { Asam asetat } 10 \% \text { ( } \mathrm{T} \\
\text { pulping } 150^{\circ} \mathrm{C}, \mathrm{t} \\
=30 \text { menit) }\end{array}$ & $\begin{array}{c}\mathrm{NaOH} \\
15 \%\end{array}$ & $\begin{array}{l}\text { NaOH 15\% (pulp } \\
80 \%+\text { LBKP 20\%) }\end{array}$ & \\
\hline 1 & $\begin{array}{l}\text { Tensile } \\
\text { strength }\end{array}$ & $\mathrm{kN} / \mathrm{m}$ & 0,63 & 0,385 & 1,321 & $\begin{array}{c}\text { SNI ISO } \\
1924-2-2010 \\
\end{array}$ \\
\hline 2 & $\begin{array}{l}\text { Tearing } \\
\text { strength }\end{array}$ & $\mathrm{mN}$ & 228,49 & 175,73 & 307,54 & $\begin{array}{c}\text { SNI } \\
0436: 2009\end{array}$ \\
\hline 3 & Brightness & $\%$ & 13,18 & 11,47 & 14,35 & $\begin{array}{c}\text { SNI ISO } \\
2470: 2010\end{array}$ \\
\hline
\end{tabular}

Keterangan : kondisi ruang pengujian : suhu $23 \pm 1^{\circ} \mathrm{C}$; RH $50 \pm 2 \%$

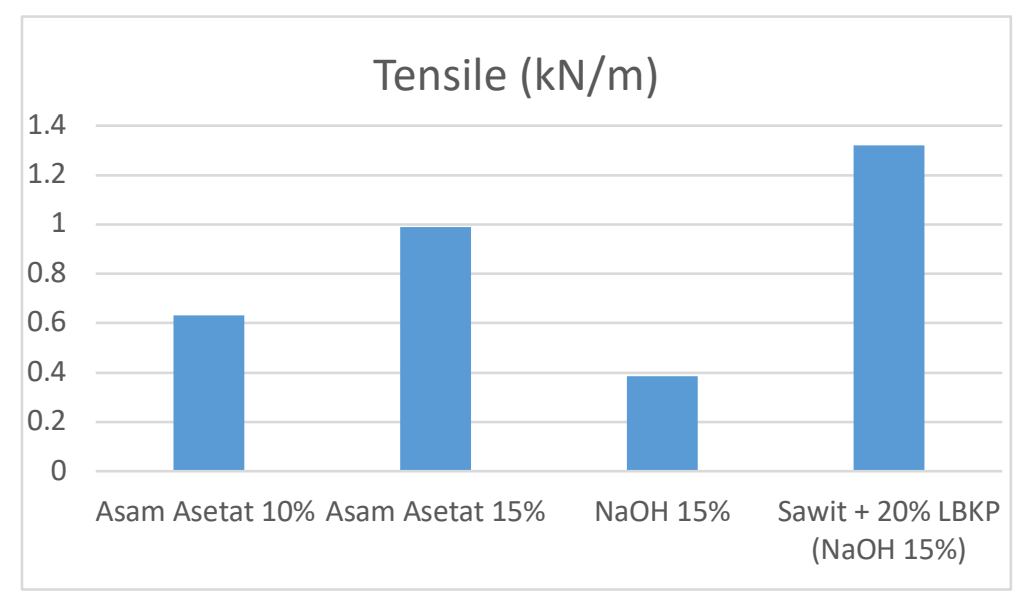

Gambar 13. Hubungan jenis dan konsentrasi larutan pemasak dengan kekuatan Tarik

Tensile strength atau kekuatan tarik merupakan salah satu parameter utama untuk melihat penggunaan bahan kimia pemasak terhadap kekuatan serat itu sendiri. Menurut Enny K. Artati , Ahmad Effendi , Tulus Haryanto dengan kenaikan asam asetat maka nilai $\alpha$ selulosa cenderung naik dan mencapai nilai maksimum konsentrasi 90\%, kenaikan tersebut karena lignin sebagai pengikat selulosa akan terpisah sehingga konsentrasi $\alpha$ selulosa semakin besar dan juga $\alpha$ selulosa merupakan sangat menentukan sifat dari ketahanan kertas itu sendiri. Dilihat dari grafik di atas bahwa semakin tinggi konsentrasi asam asetat maka daya tarik semakin baik. Jika di bandingkan dengan larutan pemasakan $\mathrm{NaOH}$ sebesar $15 \%$ kurang baik, maka adanya penambahan LBKP $20 \%$ dapat menigkatkan tensile dikarenakan kandungan serat dari wood.

Dari hasil yang didapatkan Tensile strength pada pulp pelepah kelapa sawit dengan dosis $15 \%$ lebih tinggi di bandingkan dengan pulp pulp pelepah kelapa sawit dengan dosis $10 \%$. Hal ini dapat mengindikasikan kadar selulosa (alpha,gamma,betha) pada pulp dengan dosis 15\% lebih tinggi sedangkan kadar lignin lebih rendah di bandingkan dengan dosis $10 \%$ sehingga ketahanan tarik (Tensile Strength) pulp lebih tinggi karena ikatan antar serat yang di hasilkan fibril-fibril serat dapat terbentuk dan gugus asam karboksilat $(\mathrm{COOH})$ lebih mudah untuk melepaskan $\mathrm{OH}$ - yang di sebabkan interaksi $\mathrm{COOH}$ dengan air lebih banyak dan lebih sedikit yang terhalang oleh lignin sehingga serat mengalami swelling dan ketika di refining dapat lebih mudah dan banyak bagian serat yang terfibrilasi oleh karena itu ketahanan tarik kertas lebih tinggi dan dapat meningkat.

Ketahanan tarik (Tensile Strength) lebih cendurung dipengaruhi oleh ikatan antar serat yang terbentuk sehingga jika kita mengharapkan hasil ketahanan tarik yang baik maka harus di perhatikan kondisi properties pulp (alpha) selulosa yang harus tinggi atau bisa di lihat dari viscositas pulp, dari hasil di atas maka dapat disimpulkan pemasakan lebih optimal dalam ketahanan tarik pada dosis $15 \%$. Kesimpulan ini diambil (15\% lebih baik) jika temperaturesama (150 atau 125) keduanya, jika temperatur tidak sama maka seharusnya tidak dapat dibandingkan karna variabel pemasakan berbeda, variabel kritikal pemasakan pulp yang harus di perhatikan meliputi waktu, suhu, dosis, sulfiditas, perbandingan air : berat kering bahan 
baku,(aktif alkali, efektif alkali) konsentrasi larutan pemasak. Bisa di bandingkan jika hanya salah satu dari variabel di atas yang dibedakan.

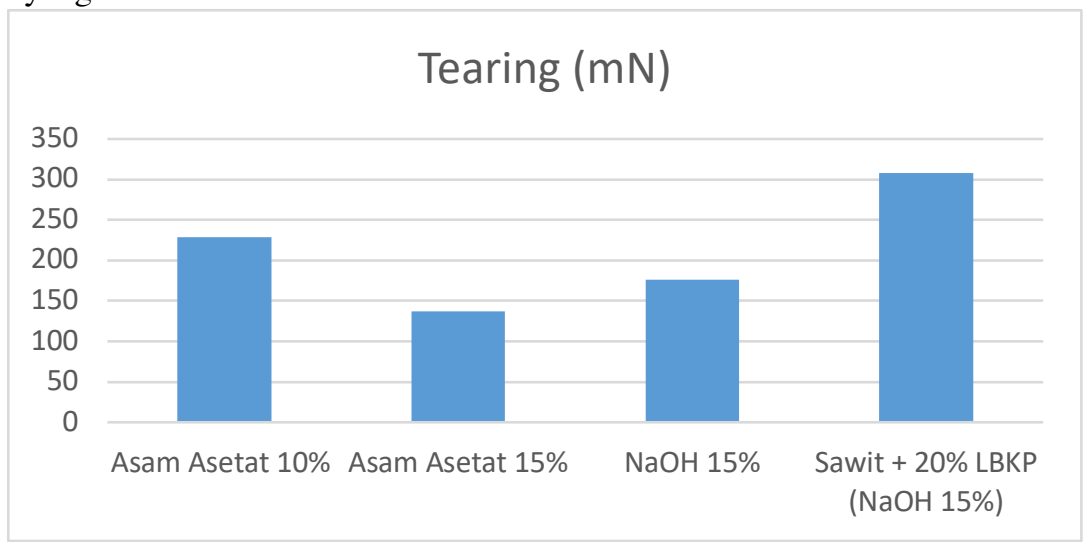

Gambar 14. Hubungan jenis dan konsentrasi larutan pemasak dengan ketahanan sobek

Ketahanan sobek (tear strength) adalah gaya yang dibutuhkan untuk menyobek kertas dalam suatu kondisi standar, semakin tinggi nilai tearing maka artinnya semakin besar ketahanan sobek kertas tersebut. Dalam kasus ini dapat dilihat dari grafik, semakin tinggi konsentrasi asam asetat maka nilai tearing semakin kecil. Maka optimum pada $10 \%$. Jika di bandingkan dengan $\mathrm{NaOH} 15 \%$ masih kurang baik, maka dengan menambahkan LBKP dapat menigkatkan nilai tearing strength. Ketahanan sobek (Tear Strength) paling di pengaruhi oleh kekuatan individual fiber dan fiber dengan rantai selulosa yang lebih panjang akan memiliki kekuatan yang lebih tinggi namun tidak hanya itu kekuatan individual fiber juga bisa berasal dari residual lignin yang masih melekat pada fibre sehingga meningkatkan kekuatan kertas.

Dari hasil pengujian di atas ketahanan sobek pulp pelepah kelapa sawit memiliki kekuatan yang lebih tinggi pada dosis $10 \%$ dibandingkan dengan dosis $15 \%$ hal ini di sebabkan oleh residual lignin yang tinggi pada dosis $10 \%$ dibuktikan dengan hasil brightness dosis 15\% lebih baik di bandingkan dosis 10\% sehingga kekuatan individual fiber lebih kuat dan akan sulit terfibrilasi pada saat rifining (di buktikan dengan nilai tensile yang lebih kecil pada dosis $10 \%$ ) sehingga nilai tear yang di dapatkan bisa lebih tinggi, oleh karena itu antara tensile dan tear memiliki kurva berbanding terbalik.

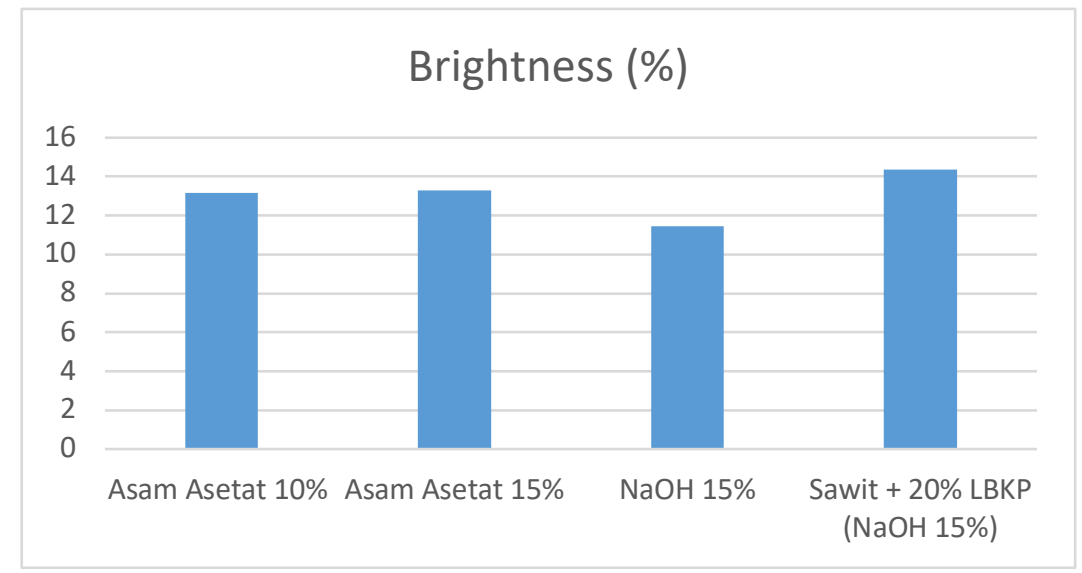

Gambar 15. Hubungan jenis dan konsentrasi larutan pemasak dengan derajat kecerahan

Brightness atau derajat kecerahan meningkat karena adanya indikasi lignin yang berkurang pada proses pemasakan, dapat dilihat semakin tinggi konsentasi larutan pemasakan semakin tinggi nilai brightness. Sedangkan penambahan LBKP juga akan mempengaruhi brightness.

Brightness (Derajat kecerahan) atau tingkat kecerahan pulp sangat di pengaruhi dan dapat mengindikasikan optimalisasi dalam proses pemasakan (delignifikasi) terutama dalam hal penghilangan lignin pada serat , semakin sedikit residual lignin maka nilai brightness akan semakin tinggi atau semakin banyak lgnin yang terdelignifikasi maka nilai brightness akan semakin tinggi.

Dari hasil di atas terlihat nilai brightness lebih tinggi pada dosis $15 \%$ hal ini di sebabkan oleh lignin yang tersisa(residual lignin) pada serat lebih sedikit di bandingkan pada dosis $10 \%$ sehingga pulp akan lebih 
cerah dan putih, sehingga dapat di simpulkan pemasakan lebih optimal pada dosis $15 \%$. Lebih baik jika dilakukan pengujian bilangan kappa (untuk mengukur residual lignin) untuk memperkuat analisis karna seperti penjelasan di atas selain residual lignin menjadi faktor yang paling mempengaruhi brightness, memang $15 \%$ lebih tinggi namun perbedaan nilai tidak terlalu jauh bisa saja dari kualitas air yang di pakai pembuatan handsheet berbeda dan pengujianya atau faktor eksternal lain.

\section{Kesimpulan dan saran}

\subsection{Kesimpulan}

1. Kertas dengan bahan baku pelepah sawit memiliki kekuatan tarik yang semakin baik dengan semakin tingginya konsentrasi asam asetat. Jika dibandingkan dengan larutan pemasakan $\mathrm{NaOH}$ sebesar $15 \%$ kurang baik, maka adanya penambahan LBKP 20\% dapat menigkatkan tensile dikarenakan kandungan serat dari wood.

2. Dalam kasus ini dapat dilihat dari grafik, semakin tinggi konsentrasi asam asetat maka nilai tearing semakin kecil. Maka optimum pada 10\%. Jika di bandingkan dengan $\mathrm{NaOH} 15 \%$ masih kurang baik, maka dengan menambahkan LBKP dapat menigkatkan nilai Tearing.

3. Tensile strengh merupakan salah satu parameter utama untuk melihat penggunaan bahan kimia pemasak terhadap kekuatan serat itu sendiri. semakin tinggi konsentrasi asam asetat maka daya tarik semakin baik. Jika di bandingkan dengan larutan pemasakan $\mathrm{NaOH}$ sebesar $15 \%$ kurang baik, maka adanya penambahan LBKP 20\% dapat menigkatkan tensile dikarenakan kandungan serat dari wood.

4. Ketahanan sobek (tear) adalah gaya yang dibutuhkan untuk menyobek kertas dalam suatu kondisi standar, semakin tinggi nilai tearing maka artinnya semakin besar ketahanan sobek kertas tersebut.

5. Semakin tinggi konsentrasi asam asetat maka nilai tearing semakin kecil. Maka optimum pada $10 \%$. Jika di bandingkan dengan $\mathrm{NaOH} 15 \%$ masih kurang baik, maka dengan menambahkan LBKP dapat menigkatkan nilai Tearing.

6. Brightness meningkat karena adanya indikasi lignin yang berkurang pada proses pemasakan, dapat dilihat semakin tinggi konsentasi larutan pemasakan semakin tinggi nilai brightness. Sedangkan penambahan LBKP juga akan mempengaruhi brightness.

\subsection{Saran}

1. Masih perlunya variasi dosis larutan pemasak dalam pembuatan pulp.

2. Perlu optimalisasi penggunaan waktu impregnasi 30 dan 60 menit dan suhu $150-175^{\circ} \mathrm{C}$.

3. Perlu optimalisasi penggunaan suhu pulping yang digunakan sebaiknya berkisar $125-160^{\circ} \mathrm{C}$ sedangkan waktu tunggu yang digunakan di 30 menit.

\section{Ucapan terima kasih}

Ucapan terima kasih disampaikan kepada Direktorat Riset dan Pengabdian Masyarakat, Direktorat Jenderal Penguatan Riset dan Pengembangan, Kementerian Riset, Teknologi, dan Pendidikan Tinggi sesuai dengan Kontrak Penelitian Tahun Anggaran 2018.

\section{Daftar pustaka}

Muurinen, E., 2000, "ORGANOSOLV PULPING a Review and Distillation Study Related to Peroxyacid", Dissertation, University of Oulu

Novianti, S., Biddinika, M. K., Prawisudha, P., Yoshikawa, K., 2014, "Upgrading of Palm Oil

Empty Fruit Bunch Employing Hydrothermal Treatment in Lab-scale and Pilot Scale", Procedia Environmental Sciences, 20, 46-54

Prawisudha, P., Irsyad, AR., Novianti, S., Yoshikawa, K., Pasek, A.D., "Hydrothermal Treatment of Oil Palm Empty Fruit Bunch to Produce Green Solid Fuel", Proceedings The 7th AUN/SEED-Net Regional Conference in Mechanical and Manufacturing Engineering 2014, October 9-10, 2014. ISBN: 978-604-911-942-2. p. 321-325., Hanoi, Vietnam

Prawisudha, P. dan Yoshikawa, K., 2013, “Optimization of Hydrothermal Treatment

Parameters to Produce Chlorine-Free Alternative Solid Fuel from Plastic-Contained Municipal Solid Waste”, Journal of Energy and Power Engineering, 7, 613-622 
JURNAL VOKASI TEKNOLOGI INDUSTRI, VOL. 1, NO. 1

Prawisudha, P., Namioka, T., Yoshikawa, K., 2012, “Coal Alternative Fuel Production from Municipal Solid Wastes Employing Hydrothermal Treatment”, Appl. Energy, 90, 298-304

Prawisudha, P., Namioka, T., Liang, L., Yoshikawa, K., 2011, "Dechlorination Behavior of Mixed Plastic Waste by Employing Hydrothermal Process and Limestone Additive" Journal of Environmental Science and Engineering, $5,432-439$

Sixta, H., 2006, "Introduction", dalam Handbook of Pulp, eds. Sixta, H., WILEY-VCH Verlag GmbH \&Co. KGaA, Weinheim, hal. 6-8

Wanrosli, W. D., Zainuddin, Z., Law, K. N., Asro, R., 2007, "Pulp from Oil Palm Fronds by Chemical Processes", Industrial Crops and Products, 25, 89-94

Wanrosli, W. D., Mazlan, I., Law, K. N., Nasrullah, R., 2011, "Influences of the Operating Variables of Acetosolv Pulping on Pulp Properties of Oil Palm Frond Fibres", Maderas. Ciencia y Technologia, 13, 193-202 